\title{
A Review of the State of LGBTQIA+ Student Research in STEM and Engineering Education
}

\author{
Madeleine Jennings, Arizona State University, Polytechnic campus
}

Madeleine Jennings is a doctoral student and graduate research assistant at Arizona State University Polytechnic Campus, pursuing a PhD in Engineering Education Systems and Design and a MS in Human Systems Engineering. They received a BS in Manufacturing Engineering from Texas State University - San Marcos. Madeleine's research interests include investigating and improving the experiences of invisible identities in engineering, such as LGBTQIA+ engineering and ex-engineering students. They are also interested in examining and critiquing the engineering and engineering education institution to determine how its current structure can serve to marginalize minority communities.

\section{Dr. Rod D. Roscoe, Arizona State University}

Rod Roscoe is an Associate Professor of human systems engineering in the Polytechnic School of the Ira A. Fulton Schools of Engineering, and a Diane and Gary Tooker Professor of Effective Education in STEM. He is affiliate faculty of the Mary Lou Fulton Teachers College, and a member of the Institute for the Science of Teaching and Learning (ISTL) and the Center for Human, Artificial Intelligence, and Robot Teaming (CHART). His research investigates how the intersection of learning science, computer science, and user science can inform effective and innovative uses of educational technologies. He is also interested in how engineering education can better prepare future engineers to consider the human elements and impacts of their work, particularly with respect to more equitable and inclusive outcomes.

\section{Dr. Nadia N. Kellam, Arizona State University}

Nadia Kellam is Associate Professor in the Polytechnic School of the Ira A. Fulton Schools of Engineering at Arizona State University (ASU). She is a qualitative researcher who primarily uses narrative research methods and is interested more broadly in interpretive research methods. In her research, Dr. Kellam is broadly interested in developing critical understandings of the culture of engineering education and, especially, the experiences of underrepresented undergraduate engineering students and engineering educators. In addition to teaching undergraduate engineering courses and a graduate course on entrepreneurship, she also enjoys teaching qualitative research methods in engineering education in the Engineering Education Systems and Design PhD program at ASU. She is deputy editor of the Journal of Engineering Education.

\section{Dr. Suren Jayasuriya, Arizona State University}

Suren Jayasuriya is an assistant professor jointly between the School of Arts, Media and Engineering (AME) and the School of Electrical, Computer, and Energy Engineering (ECEE) at Arizona State University. Prior to this, he was a postdoctoral fellow at the Robotics Institute at Carnegie Mellon University from 2016 - 2017. He received his Ph.D. in Electrical and Computer Engineering from Cornell University in 2017, and a B.S. in Mathematics and a B.A. in Philosophy from the University of Pittsburgh in 2012. His research interests are in computational imaging and photography, computer vision and graphics, sensors, and education. 


\title{
A Review of the State of LGBTQIA+ Student Research in STEM and Engineering Education
}

\begin{abstract}
The purpose of this critical literature review was to generate awareness of the LGBTQIA+ engineering student experience and research on this community, while also highlighting areas that are lacking or receiving insufficient attention. This work is part of a larger project that aims to review engineering education research with respect to LGBTQIA+ students, higher education faculty and staff, and industry professionals. This literature review was conducted in two phases. First, works from non-engineering disciplines were reviewed to identify popular threads and major areas of research on the LGBTQIA+ student experience. This phase was not an exhaustive review; rather, it was meant to establish specific themes of importance derived from the larger body of literature on the LGBTQIA+ student experience. Second, a literature review identified how engineering-specific research on the LGBTQIA+ student experience aligned with these themes. We identified several themes in the first phase of the literature review: (1) Climate, (2) LGB Monolith, (3) Intersectionality, and (4) Identity Development. Engineering and engineering education literature demonstrated similar themes, although this body of work was unique in the exploration of LGBTQIA+ coping strategies and the use of the technical/social dualism framework. Overall, the engineering education literature on LGBTQIA+ student experiences seemed relatively underdeveloped.
\end{abstract}

Keywords - LGBTQIA+, Inclusion \& Diversity, Literature Review, Interdisciplinary Higher Education Research

\section{Introduction}

Research on the LGBTQIA+ Community

Throughout this paper, we reference the term "LGBTQIA+," which is an umbrella acronym used to describe any person who does not identify with heterosexual and cisgender norms (Gold, 2019). Recent research on the LGBTQIA+ student experience shows a growing interest on this topic, both within and outside of the field of engineering education (Lange et al., 2019). Within this encouraging trend, the disciplines that have placed the greatest sense of urgency on understanding this community's experiences appear to have been higher education, psychology, and queer and gender studies. Research from these fields have shown that LGBTQIA+ students experience heightened levels of verbal and physical violence, harassment, and discrimination. As a result of experiencing such mistreatment on a regular basis, many students have reported lower levels of satisfaction and performance in school or the workplace, and lower levels of general wellness overall (Burgess et al., 2007; Sears \& Mallory, 2011). Identity development of LGBTQIA+ college students is also different from non-LGBTQIA+ students (Bilodeau \& Renn, 2005). Finally, intentional efforts from academic institutions -- programs and policies that increase visibility, protection, and support for these students, along with supplying campus services and support -- enhance the positive aspects of their experience (Evans, 2002; Pitcher et al., 2018).

The repertoire of literature surrounding diversity and inclusion of marginalized groups in engineering is robust and well-established. Ample research details the underrepresentation of women and students of color in engineering with respect to recruitment and retention, and 
describes the causal roles of both obvious and subtle forms of discrimination, lack of mentorship and role models, and more (Bebbington, 2003; Ohland et al., 2011). In contrast, the perspectives and experiences of LGBTQIA+ engineering students represented in the engineering and engineering education literature reviewed in this paper appeared to be nascent. In addition, the specific or unique experiences, benefits, and challenges of LGBTQIA+ engineering students seemed less well known. Although there has been exploratory work on the LGBTQIA+ engineering student experience (Cech \& Waidzunas, 2011; Cech \& Rothwell, 2018; Haverkamp et al., 2019), it was challenging to locate engineering-specific work that addressed a more holistic view of the LGBTQIA+ community. Often, research with the LGBTQIA+ engineering student community neglected the experiences of transgender and gender nonconforming (TGNC) people and queer People of Color (QPOC). This literature review explored the current status of the field of research on the LGBTQIA+ engineering student experience.

\section{Research Questions}

We were interested in determining how the body of literature on the LGBTQIA+ student experience in engineering compares to literature and research on the LGBTQIA+ student experience from other interdisciplinary higher education fields. To accomplish this, we conducted a thematic review on interdisciplinary higher education research conducted on and with the LGBTQIA+ community. Following this stage, we conducted a systematic literature review to compare the existing literature on the LGBTQIA+ student experience within the field of engineering education to that of the interdisciplinary higher education literature. The following research questions informed this review:

1) What are major, overarching themes on the LGBTQIA+ student experience present in a broader body of interdisciplinary higher education literature?

2) How do the overarching themes found in the broader body of literature manifest (or not) in the engineering and engineering education research literature?

\section{Methods}

\section{Theoretical Framework}

Borrego et al. (2014) discusses the purposes and procedures involved in conducting a systematic literature review. In more mature fields of study, systematic literature reviews are often conducted to evaluate or crystalize theory from a body of work. Systematic literature reviews also can be written to capture the historical development of a research trend. Within engineering education research, however, systematic literature reviews are most often conducted to outline the state of a body of literature, or to point to gaps in a body of research. Systematic literature reviews are often needed if a body of work informs policy, or if future research efforts need direction from the synthesis of existing work.

Research questions and carefully scoped search criteria typically guide qualitative systematic literature reviews (Borrego et al., 2014). Resource analysis is guided by an "appraisal" process, involving a protocol of questions designed to determine the content and quality of a study. Each study is synthesized, and the reviewer evaluates within and between studies to establish links, evaluate quality and content, and draw conclusions. 
We relied on other literature reviews to provide us a sense of where interdisciplinary higher education disciplines focus their efforts with regard to research with the LGBTQIA+ student community. However, we utilized the systematic literature review framework for engineering education to inform the literature review for engineering and engineering education works.

\section{Data Collection \& Analysis}

The literature review for this project was conducted in two stages. During the first stage, literature from several fields, which we refer to as interdisciplinary higher education research, was surveyed on the LGBTQIA+ student experience. Examples of these diverse fields included psychology, higher education, sociology, anthropology, art education, public policy, and business management. All disciplines were considered in the search; however, much of the work we found surrounding the LGBTQIA+ student experience had been conducted in higher education, psychology, and gender/queer studies. Therefore, these disciplines were heavily drawn upon to inform the first stage of this review. A non-systematic, general thematic review was conducted using databases such as Google Scholar, ERIC, and PsychINFO. Searches contained keywords in the Boolean input function for these databases (e.g., ("LGBT" or "lesbian" or "gay" or "bisexual" or "transgender" or "queer" or "gender nonconforming" or "homosexual") AND ("student" or "college" or "university")). Results from this search were extensive; we thus focused our attention on existing literature reviews and similar publications to capture the most representative themes and patterns of the broader body of interdisciplinary higher education literature.

During the second stage, a systematic review located all relevant engineering-specific work on the LGBTQIA+ student community. This search considered refereed engineering or engineering education-specific journals or conference proceedings, and focused on publications that explicitly examined the LGBTQIA+ engineering student experience. Search databases included Google Scholar, EI Compendex, ASEE Peer Document Repository, IEEE Transactions on Education, Journal of Engineering Education (JEE) and Advances in Engineering Education (AEE) archives. Additionally, we obtained engineering-related content appearing in education, gender studies, and related journals and conference proceedings.

Our search yielded a large volume of works (over 1,900 in EI Compendex and over 11,000 in Google Scholar) that were only marginally or not at all related to our search criteria. Works that best fit our search criteria from the first 350 results from these two databases were collected. After obtaining relevant publications resulting from these searches, we inspected their references to reveal additional sources. Because our specific focus was LGBTQIA+ engineering student experiences, we did not obtain works pertaining only to LGBTQIA+ engineering faculty, faculty, or others.

Each publication was evaluated with respect to inclusion and exclusion criteria (e.g., peerreviewed journal article or conference proceeding on relevant topics), and then integrated within the broader analysis. For both stages of the literature review, an online form was implemented to annotate each publication in a systematic, streamlined, and transparent manner. Annotations recorded (a) the stated purpose of the study, (b) major findings, (c) key contributions to the literature, (d) potentially unique features of the research, and (e) readers' interpretation of the 
themes addressed in publication. These annotations were then analyzed to identify the overarching themes reported in this paper.

Overall, twenty-two engineering or STEM-specific papers were included. Six of these publications were published in peer-reviewed journals, and fifteen publications appeared in refereed conference proceedings. One publication did not appear to be peer-reviewed. We included it because it met our other search criteria and represented a topic that had not been discussed in other works. Of the entire dataset, eight publications implemented primarily quantitative methods and nine publications emphasized qualitative methods. Two of the remaining publications were classified as mixed methods, and three others were classified as "other." Details regarding included publications are reported in Appendix A. For clarity, we adopted APA formatting guidelines (rather than IEEE formatting) to assist readers with identifying cited research.

\section{Limitations}

Research on the LGBTQIA+ engineering experience is more expansive than this review represents, as this literature review only examined the state and status of the research surrounding the LGBTQIA+ engineering student experience. As such, we intentionally left out literature on LGBTQIA+ engineering faculty and industry professionals. We also left out much of the literature on efforts to improve the climate of engineering for LGBTQIA+ students through faculty training efforts. We intend to address works on LGBTQIA+ faculty/staff and industry professionals in later works.

Our methods for reviewing literature are heavily interpretivist. The lead author on the paper identifies with the LGBTQIA+ community, and is becoming familiar with feminist, queer, and race theories that they feel have been absent from engineering and engineering education research. This interpretivist lens was informed by the lead author's own experiences as a queer engineering student. This interpretivist lens also enabled analysis and recommendations with QPOC and TGNC experiences in mind.

We felt that the body of research with the LGBTQIA+ engineering student community was relatively small. As such, we did not synthesize this body of literature. Instead, we organized the themes within the literature to gain an understanding of certain authors' spheres of influence and popular topics of investigation. We also chose to conduct a thematic analysis of the engineering and engineering education research so that we could more easily highlight the absence of themes such as intersectionality and queer theory, which were themes that were more easily detectable in the interdisciplinary higher education literature.

\section{Positionality Statements}

The lead author on this paper, Madeleine Jennings, is a white, middle-class, queer graduate student at Arizona State University. They are interested in restructuring the engineering institution to become less hostile to marginalized groups using tenants from queer theory, feminism, and anarchism. Madeleine prefers qualitative methodologies when working with "small numbers" (Slaton \& Pawley, 2018), and believes that quantitative research on "small numbers" communities such as the LGBTQIA+ community serves to marginalize these communities further. They view this literature review as a call-to-action for engineering 
education researchers to engage in work with LGBTQIA+ students using these frameworks, methodologies, and epistemologies.

Dr. Rod Roscoe is an associate professor in the Human Systems Engineering program at Arizona State University, and serves as Madeleine's advisor for their MS in that program. He studies education and learning from the perspectives of self-regulation and sociotechnical systems. Dr. Roscoe is deeply interested in inclusion and equity issues in human-centered engineering and design.

Dr. Nadia Kellam is an associate professor in the engineering education program at Arizona State University, and serves as Madeleine's advisor for their PhD. In general, Dr. Kellam is interested in using research approaches that encourage us to listen more deeply to the data. While she appreciates the value of this literature review in developing a pulse of the current state of research around LGBTQIA+ engineering students, she is looking forward to conversations with LGBTQIA+ engineering students that will help us begin to develop understandings of their experiences in engineering education and how their experiences reflect broader structural and societal inequalities present in engineering education.

Dr. Suren Jayasuriya is an assistant professor in the Arts, Media, \& Engineering program at Arizona State University, and serves as Madeleine's mentor on multiple projects. His background and research are in electrical engineering and computer science, although he has new research projects in engineering education, including epistemologies and student experiences in interdisciplinary engineering and the arts/humanities programs. His subjectivity in this project mostly focused on the application of queer theory and philosophy in the works collected in this literature review, including analyzing how effectively those ideas and methods are incorporated throughout the literature.

\section{Findings}

Interdisciplinary Higher Education Research Findings

Much of the research presented in this section on LGBTQIA+ students originated from higher education, queer studies, and psychology research. Consequently, this interdisciplinary higher education literature review relied heavily on work from this area. The themes that emerged in this first stage were (1) Climate, (2) LGB Monolith, (3) Intersectionality, and (4) Identity Development.

1. Climate - As Renn (2010) mentioned, climate is a large theme within the body of research conducted on LGBTQIA+ students. Research on this topic often asked heterosexual, cisgender students about their attitudes towards students within the LGBTQIA+ community via survey. For example, Woodford et al. (2012) conducted a quantitative study which sought to determine predictors in heterosexual students about their attitudes toward the LGBT community as a whole, as opposed to asking about certain sub-communities within the LGBTQIA+ community. Works of this nature were most often quantitative, but can also be qualitative in nature. For example, Evans \& Harriott (2004) conducted an ethnographic study to explore how heterosexual students' perceptions about the LGBTQ+ community changed when they were exposed to the community. Work that followed this theme could also take the form of asking LGBTQIA+ students about the climate of their university to assess attitudes surrounding the 
LGBTQIA+ community. The campus climate for queer-identifying and TGNC students, according to Greathouse et al. (2018), remains chilly or violent. This same study indicated that $72.4 \%$ of trans-spectrum students and $42.3 \%$ of queer-spectrum students reported that they witnessed discrimination on campus, as opposed to $27.6 \%$ of heterosexual, cisgender students. LGBTQIA+ students were also more likely to be victims of violence and discrimination than their cisgender, heterosexual peers. Queer- and trans-spectrum students were also significantly more likely to report "below average" mental health compared to cisgender, heterosexual peers.

2. LGB Monolith - We termed this theme as the LGB Monolith, as it largely focused on the experiences of primarily white, cisgender, middle-class, and homosexual men and women. There were some exceptions belonging to bisexuals in the same demographic groups. Largely, this theme described older works (late 1990's to early 2000's), and this body of work constituted the foundation of what researchers know about the experiences of the LGBTQIA+ community (D'Augelli, 1992; Dilley, 2002). Privileged members of the LGBT community are largely white, male, cisgender, and middle-class. Ongoing research on this group is likely enforced by sampling. As Renn (2010) mentioned, "there is no longer a gap in the literature" with regard to LGB research in higher education. This trend seems to be reflected in other disciplines. Renn did, however, mention that as of 2010, there was still a gap in the literature with regard to work with the TGNC and QPOC community. Lange et al. (2019) further confirmed with their more recent literature review that there is still a gap in the research with regard to the TGNC and QPOC experience in higher education. It would seem that other fields to tend agree that the TGNC and QPOC population has been neglected, as well (Johnson, 2001).

3. Intersectionality - More recent work discussed the intersectional nature of the LGBTQ+ community, and provided a welcome challenge to the LGB monolith. Specifically, work in this area deals with the TGNC communities, as well as the larger queer community in general, with respect to racial/ethnic, class, disability, and other identities. Both Renn (2010) and Lange et al. (2019) mentioned in their literature reviews that not enough work has focused on this topic. Newer research appeared to be focusing more on the TGNC and QPOC communities, however. For example, Marine \& Nicolozzo's (2014) conducted a discourse analysis of the language used by LGBTQ Centers, which analyzed the inclusion of TGNC people in these centers, and, thus, challenged the LGB monolith. Duran's (2019) systematic literature review of QPOC in higher education and higher education research highlighted the importance of acknowledging the intersectionality of QPOC by providing examples of the diversity of QPOC research participants from research studies.

4. Identity Development - Models that serve to map out LGBTQIA+ students' identity development in college or university settings were prevalent in interdisciplinary higher education research. These models, as defined by Bilodeau \& Renn (2005), vary in nature and epistemology. Often, older models were designed from positivistic and linear perspectives, which expected the student to "arrive" at their fully developed identity. Other more constructivist and post-modern models were grounded in queer, critical, and feminist theory, and explored how one's LGBTQIA+ identity develops alongside other identities, as demonstrated by Abes \& Kasch (2007). In addition to LGBTQIA+ identity development, this theme also included the identity development of non-LGBTQIA+ people using queer identity development models (Evans \& 
Harriott, 2004). An emergent research theme was the creation, characterization, and/or validation of LGBT identity development models for LGBTQIA+ or non LGBTQIA+ students.

Climate, LGB Monolith, Intersectionality, and Identity Development were the major, overarching themes that emerged in the broader body of literature, as summarized above. However, there were trends that we found somewhat frequently, but could not necessarily classify as themes. For example, there was a roughly chronological evolution of trends in LGBTQIA+ student research in the broader body of literature (Renn, 2010). This trend began with the LGB Monolith, which is defined by research that primarily represents the experiences of white, cisgender, middle- to upper-class, homosexual men and women (D'Augelli, 1992; Lopez \& Chims, 1993). This body of work constitutes the foundational research that lays out the LGBTQIA+ student experience. This period of research is followed by works that discuss LGBTQIA+ student identity development, which were initially positivistic and linear in nature (Bilodeau \& Renn, 2005). Later, research on LGBTQIA+ students evolved to take on a more intersectional lens, and identity development models became additive or cumulative in nature. The latest evolution of LGBTQIA+ research adopted a post-modern interpretation, which rejects identity as additive, and instead examines the experience of LGBTQIA+ individuals through the lenses of queer theory, critical theory, critical race theory, and feminism (Duran, 2019; Lange et al., 2019). Newer works also addressed the apparent gap in the literature with regard to researchers using queer theory that focus on race and ethnicity, known as "quare theory," as a framework for exploring LGBTQIA+ student experiences (Johnson, 2001; Means, 2017)

\section{Engineering-Specific Research Findings}

The first paper breaking ground on LGBTQIA+ student issues in engineering was published in 2009 at the annual ASEE conference (Cech \& Waidzunas, 2009). Since this flagship paper on the topic, Cech has arguably been the most influential researcher in this space, having been an author on seven out of the twenty-two works we reviewed. Waidzunas and Farrell were also prolific researchers in this space, having been lead or co-author on five and four publications, respectively. Below, we discuss the themes that were most prominent within the body of work on the LGBTQIA+ engineering student experience, which often overlapped with each other within individual papers. These themes were (1) Climate, (2) Coping Strategies, (3) Policy Change, (4) LGB Monolith, and (5) Technical/Social Dualism.

1. Climate - Much of the groundwork that was conducted on the LGBTQIA+ student experience within the field of engineering education has focused on the climate within engineering programs and the attitudes of heterosexual engineering students toward their LGBTQIA+ peers. Climate, as defined within the context of engineering education, is perceived by marginalized students, and is reflective of the broader, dominant culture that operates within the program (Cech \& Rothwell, 2018; Cech \& Waidzunas, 2011). The climates within engineering programs and classrooms are perceived as "chilly" by LGBTQIA+ students. This chilliness is often driven by a range of behavior and attitudes from heterosexual and cisgender students and faculty, including subtle indications of disapproval about one's sexual orientation or gender identity (Haverkamp et al., 2019; Linley et al., 2018), to outright and explicit verbal and/or physical violence (Cech \& Rothwell, 2018). 
The flagship works discussing the LGBTQIA+ engineering student experience demonstrated specific instances of chilliness within the engineering academic climate for LGBTQIA+ students, as told by LGBTQIA+ engineering students through qualitative data (Cech \& Waidzunas, 2009; Cech, 2013; Cech \& Waidzunas, 2011; Trenshaw et al. 2013). They revealed that engineering, being an apolitical space, often forces queerness out, and that people belonging to the LGBTQIA+ community are often seen as less than. Cech \& Rothwell's (2018) quantitative study on LGBTQ inequality in engineering revealed that across eight different universities, LGBTQ students reported heightened levels of marginalization and discrimination as compared to their non-LGBTQ peers, which corresponded to more health issues for these students, such as insomnia, depression, and anxiety (Cech et al., 2017; Cech \& Rothwell, 2018). Additionally, LGB students are reported to persist in STEM fields 7\% less than non-LGB students despite more engagement in undergraduate research, likely because of issues with marginalization in their programs (Hughes, 2018).

Between Cech et al.'s (2011) and (2018) journal publications, there were a number of works that examined the engineering climate for LGBTQIA+ students through different lenses. Specifically, the climate within engineering programs was measured quantitatively by surveying forty-seven engineering deans about their feelings toward LGBTQIA+ inclusion in their programs, how they perceived their faculty's and student's feelings about LGBTQIA+ inclusion, and if they felt that there were issues with inclusion within their programs (Cech et al., 2016). They found that a majority of engineering deans supported LGBTQIA+ inclusion initiatives in their programs, but believed that their faculty, staff, and students did not. Additionally, engineering deans appeared to underestimate the amount of problems with LGBTQIA+ inclusion that were present within their programs. Trenshaw (2018) investigated how the representation of LGBTQIA+ people in engineering spaces affected LGBTQIA+ engineering students' perception of engineering climate, as well. Linley et al. (2018) examined the LGBTQIA+ STEM student experience through qualitative data. They relied on ecological, climate, and social dualism frameworks. Linley et al. found that LGBTQIA+ STEM students in socially-oriented STEM fields perceived a more friendly climate, whereas students enrolled in technical, applied majors perceived a chillier climate. Haverkamp (2018) also theorized that many of the issues that TGNC students face in engineering are caused by biological essentialism, which is the belief that assigned sex dictates gender identity and that there are only two genders, which are male and female. This belief is associated with apolitical leanings.

Interestingly, Rohde et al.'s (2017) study investigated the differences between self-identified cisgender engineering students and engineering students who identify themselves as either male or female and do not identify as cisgender. They found that those who identify as cisgender are more likely to care about or aim to utilize their engineering degree to address social justice issues. Although this study is about allied engineering students, we still believe it is relevant to the study at hand, as it provides context for both measuring and understanding the climate for marginalized engineering students, including LGBTQIA+, through queer language.

There has been recent work regarding TGNC students, which is a sub-community within the broader LGBTQIA+ group that has not explicitly been studied previously. While these students belong to the broader LGBTQIA+ community, their experiences are not always translatable when compared to the experiences of cisgender members of the LGBTQIA+ community. For 
example, an auto-ethnographic, qualitative study conducted with two transgender queer women both confirmed researched trends of the marginalization of LGBTQIA+ students in engineering, and brought to light that TGNC engineering students often face unique challenges, such as introducing name and pronoun changes to peers (Haverkamp, 2018; Haverkamp et al., 2019). The students in this study also discussed the issues relating to the lack of community for them within engineering spaces, and often found this sense of community within online spaces. The lack of in-person communities within engineering spaces further sequestered TGNC students from the broader engineering community. The result of this finding was one student leaving engineering altogether, which they reported vastly improved their mental health. The lack of community for LGBTQIA+ engineering students stems from the embodiment of heteronormativity within the culture of engineering (Riley, 2013). In addition to health issues, the culmination of the "chilly" climate within STEM spaces has also been shown to have an effect on LGBTQIA+ retention in computing (Stout \& Wright, 2016). LGBTQIA+ computing students that report a lower sense of belonging within their programs are more likely to leave their programs (Stout \& Wright, 2015, 2016).

On a brighter note, Boudreau et al. (2018) explored how engineering spaces may be becoming more inclusive to LGBTQIA+ engineering students. Cultural changes had begun to make younger people more accepting of LGBTQIA+ students on campus. Additionally, incorporating humanities and social sciences into engineering programs made engineering spaces less apolitical, thus improving the climate for students. Openly queer or visible faculty allies also improved the climate for LGBTQIA+ students. Another study cited that, although other students were a main source of stress for LGBTIA+ STEM students, having faculty allies made these students' experiences much more manageable (Linley et al., 2018). .

2. $\quad$ Coping Strategies - As discussed prior, the climate for LGBTQIA+ engineering students is generally perceived as "chilly" (Cech \& Waidzunas, 2011). LGBTQIA+ students in engineering were shown to adopt coping strategies to help them navigate this climate. Cech \& Waidzunas' (2011) qualitative study explored the experiences of the LGBTQIA+ engineering community in general. They found that these students navigated the heteronormative and "chilly" or hostile environment by covering their identities, passing as straight, and compartmentalizing their social and academic/professional lives. The implications of these coping strategies were diminished mental health, dissatisfaction or anxiety with their career choice, and increased levels of isolation from peers. This study, however, focused only on cisgender members of the LGBTQIA+ community.

TGNC students have the added challenge of "deadnaming," or being consistently called by the name and pronouns that align with the gender that they no longer identify with. TGNC students also face confusion or even violence from peers in the event that they are physically transitioning. This, according to Haverkamp et al. (2019), required TGNC students to downplay or hide their gender identities and isolate themselves from their engineering and university community. Often, this meant skipping class or group work to prevent being identified as TGNC. Haverkamp et al. mentioned also that these students find solace and community in online spaces, instead of on-campus spaces. This need for community was so intense for one participant in this study that they dropped out of school altogether, which they said vastly improved their mental health. 
3. Policy Change - An interesting trend that we found in the engineering-specific body of literature is the focus on policy change to help protect the LGBTQIA+ engineering population. The uptick in works relating to the LGBTQIA+ engineering experience has created a rise in literature that introduces ideas for policy change to improve the experience of LGBTQIA+ engineers. Policy improvements that were reported ranged from the ratification of diversity and inclusion statements of engineering organizations to include LGBTQIA+ (Bowman \& Madsen, 2018), to the implementation of SafeZone trainings for allies (Farrell et al., 2017; Guerra et al., 2016), to a broader call-to-action to change the culture of engineering to be more genderinclusive and less heteronormative (Cech, 2013; Haverkamp, 2018). The policy changes that were suggested most often include faculty training, protections for LGBTQIA+ students, and the addition of social sciences and humanities to fight the meritocratic, apolitical climate within engineering spaces.

4. LGB Monolith - Despite an increasing amount of work on the topic since 2009, research on the LGBTQIA+ student engineering experience is still nascent. Though researchers undertake efforts to recruit a diverse sample of research participants, much of the work that we reviewed was focused on the gay, lesbian, and bisexual perspective, and very heavily focused on the cisgender perspective (Cech \& Waidzunas, 2009; Cech \& Rothwell, 2018; Hughes, 2017, 2018; Rohde et al., 2017). Often, this was not the researchers' fault. Students who reside at more than a few intersections of marginalized identity often "fell out" of quantitative analysis, due to small numbers of representation within engineering. This same issue of representation was still persistent in qualitative research, as well. The result of research that was conducted on primarily cisgender members of the LGBTQIA+ community - however valuable it actually is - is work

that is only generalizable to the cisgender portion of the community, which could result in further alienization of QPOC, TGNC, and a-, bi-, demi-, or pansexual engineering students (Marine \& Nicolazzo, 2014).

5. Technical/Social Dualism in Engineering - There was a frequent utilization or mention of the Technical/Social Dualism framework throughout the broader body of literature regarding the LGBTQIA+ engineering student (Faulkner, 2000). Publications that Cech has written often incorporated this framework. Since Cech's papers on the LGBTQIA+ engineering student experience were heavily cited, this framework often appeared in some way in much of the research. This framework theorizes that dichotomies within the social systems of engineering disenfranchise marginalized groups by associating them with the "lesser" dualism. For example, gay men are stereotyped as being feminine. Since women are often associated with more socially-oriented areas of study or occupation, gay men are often shut out of engineering in ways similar to women (Cech \& Waidzunas, 2011). This framework has been used to analyze the experiences of LGBTQIA+ engineering students in the most impactful and seminal publications (Cech \& Waidzunas, 2009, 2011; Cech \& Rothwell, 2018; Linley et al., 2018). It has also been mentioned in other journal and conference articles in varying degrees, with regard to the LGBTQIA+ community (Farrell et al., 2017; Hughes, 2017; Leyva et al., 2016).

\section{Discussion}

This literature review examined the state of engineering and engineering education-specific literature regarding the LGBTQIA+ student experience compared to interdisciplinary higher 
education fields. Compared to research on LGBTQIA+ students in the broader body of literature, engineering and engineering education research is far less developed. Although there has been an increase in interest in the LGBTQIA+ experience in engineering since 2009, we feel that the body of current work on engineering students is still nascent and fundamental. In general, more research with this community is vital in order to claim that we, as engineering education researchers, understand the experiences of diverse LGBTQIA+ engineers. In addition, we identified a fairly small community of scholars who have worked on research with the LGBTQIA+ engineering community. We understand that this phenomenon is a function of the nascency of this thread of research. However, we believe that an increase in the number of scholars that conduct research in this area will benefit the LGBTQIA+ engineering community by increasing the diversity of thought within the body of research on this topic, as well as normalizing this community's presence within engineering. The severe lack of research on the TGNC and QPOC communities in engineering is likely due, in part, to the lack of researcher diversity. Other factors could be the inherent difficulty of conducting research with the LGBTQIA+ population, due to the diversity of the community and the lack of LGBTQIA+ people in engineering, in general.

Our findings indicated that a majority of engineering and engineering education research focuses on what the climate is like for LGBTQIA+ students. This research is a vital first step into understanding how this community experiences engineering programs. Research on the climate for LGBTQIA+ engineering students also provides substantiation for culturally relevant pedagogy, refining policy changes, and revising inclusion and diversity strategies in academia and industry. It is also useful because it further confirms the toxicity within engineering programs that has been shown to affect women, students of color, students from low socioeconomic backgrounds, and other marginalized groups. However, much of the research exploring the climate within engineering is heavily focused on groups that belong to the LGB monolith. We felt that the erasure of the 'TQIA+' portion of the community was partially unintentional. There are many sub-communities within the greater LGBTQIA+ community, some of which can be fairly small and difficult to represent in large-scale studies. For example, we could find no studies that specifically examined the experiences of TGNC QPOC. However, there have been studies which we have included in this review that have successfully represented some of the smaller sub-communities within LGBTQIA+. For example, Haverkamp et al. (2019) broke the silence on the TGNC engineering experience in a collaborative autoethnography with two engineering students who identified as such.

We noted also that there was little to no application of queer theory with regard to researching the LGBTQIA+ engineering student community. The exception was work having to do with TGNC students, and to some extent, queerness as a state of being in engineering (Haverkamp, 2018). However, it is worth mentioning that we were able to find some queer theory-inspired work in engineering spaces, which did not necessarily discuss the LGBTQIA+ population. Rather, these works utilized queer theory and critical analysis to critique the culture of engineering and engineering education (Riley, 2013, 2017; Slaton \& Pawley, 2018). This is paradoxical, according to Renn (2010), who cites a similar trend in the higher education literature - that is, the queer experience is not often analyzed or understood through the framework established to understand queerness. 
In addition to the lack of queer theory represented in engineering education research, there was not much discussion on identity development in engineering education as opposed to other bodies of literature. Only one paper that we reviewed from the engineering education literature explored the engineering, queer, or other identity development of LGBTQIA+ engineering students (Hughes, 2017), though this topic has been explored at length in other disciplines. Proportionally, however, there seemed to be more explicit discussion surrounding coping mechanisms within engineering education than the broader body of literature (Cech \& Waidzunas, 2009, 2011; Haverkamp et al. 2019; Lange et al., 2019), though this work tended to focus on the ways that LGBTQIA+ students navigated toxic systemic structures as opposed to changing these structures to be more inclusive.

Finally, research seemed to be more representative of the diversity within the LGBTQIA+ engineering community when it was conducted in qualitative settings with a smaller handful of diverse students. Engineering education research often tends to value larger, systematic, quantitative studies that are generalizable to a wider population (Riley, 2017). These studies are valuable for making generalizations about larger populations, including the LGBTQIA+ engineering community. However, we note that the climate within the engineering education community seems to be changing to value "small numbers" (Slaton \& Pawley, 2018) research. This type of research is especially valuable and important for capturing voices that "fall out" of these large-scale, quantitative studies. Particularly within the LGBTQIA+ student community, "small numbers" studies are useful for understanding the experiences of TGNC and QPOC, who often find themselves as the "only" in their programs.

\section{Future Considerations}

Engineering education research has, we feel, sufficiently established a baseline understanding of the LGBTQIA+ student experience through both qualitative and quantitative methods. However, there is less work on the TGNC and QPOC experience. Unarguably, this review demonstrates that more research must be conducted with the LGBTQIA+ engineering student community in order to claim that engineering education as a discipline understands their experiences. Although we are especially excited about qualitative, "small numbers" research with this community, we recognize that there is a need for more responsible, thorough, and thoughtful research in general. Because of this, we offer some answers to potential questions that researchers may have when considering conducting research with the LGBTQIA+ community. In addition, we ask a few questions without answers that should be considered when conducting engineering education research.

Who can conduct research with the LGBTQIA+ engineering community? We believe that anybody can conduct research with this community, so long as they have responsibly educated themselves about this community's struggles and victories. This helps to establish trust with the community. Researchers that are interested in becoming familiar with the LGBTQIA+ community can complete SafeZone training, available on most campuses and online. They can also seek out LGBTQIA+ media such as podcasts, blogs, or TV shows, which often examine LGBTQIA+ issues and current events.

How can researchers conduct responsible research with the LGBTQIA+ community? The LGBTQIA+ community has been subject to unique and particularly violent forms of harassment, 
discrimination, and erasure within society, including within the engineering institution. Within the LGBTQIA+ community, TGNC people and QPOC have shouldered the brunt of societal abuse. Examining one's own reflexivities and biases about the LGBTQIA+ community is a necessity if the work is to remain ethical.

We pose some questions for all engineering education researchers to consider when doing research that may involve LGBTQIA+ students:

- Do I have some understanding of the LGBTQIA+ community, so that I can empathetically navigate an interview with someone from this community?

- How does my positionality as a [describe yourself here] influence my interactions with the LGBTQIA+ community?

- Do I have any unexamined biases around LGBTQIA+ communities?

- Do my demographic surveys ask questions that are inclusive of QPOC and TGNC identities?

\section{Conclusions}

We conducted a literature review to uncover gaps and future directions for research around the LGBTQIA+ engineering student experience. First, we identified themes within the interdisciplinary higher education literature, including the following: 1) Climate, 2) LGB Monolith, 3) Intersectionality, and 4) Identity Development. In the next phase of this work, we conducted a systematic literature review of engineering-specific research on the LGBTQIA+ experience. Using thematic analysis, we found that Climate and LGB Monolith aligned across interdisciplinary higher education and engineering education research. Differences included a focus on coping strategies, policy change, and technical/social dualism in engineering and engineering education research. We concluded this paper with questions for consideration when conducting research specifically focused on an aspect of LGBTQIA+ engineering students and when conducting research that may include students from this minoritized population.

\section{Acknowledgements}

First and foremost, the authors would like to thank Jenna Forrey for her assistance on this project. The authors would also like to thank those scholars and researchers that have broken ground in this space and continue to conduct research on the LGBTQIA+ engineering experience. It is incredibly vital. This material is based upon work supported by the National Science Foundation under Grant No. EEC-1830730. Any opinions, findings, and conclusions or recommendations expressed in this material are those of the author(s) and do not necessarily reflect the views of the National Science Foundation. The authors would also like to acknowledge support from a combined grant from the Herberger Institute for Design and the Arts, as well as the Mary Lou Fulton Teachers College at Arizona State University.

\section{References}

Abes, E. S., \& Kasch, D. (2007). Using Queer Theory to Explore Lesbian College Students' Multiple Dimensions of Identity. Journal of College Student Development 48(6), 619636. doi:10.1353/csd.2007.0069.

Bebbington, D. (2002), Women in Science, Engineering and Technology: A Review of The Issues. Higher Education Quarterly, 56: 360-375. doi:10.1111/1468-2273.00225 
Bilodeau, B.L. and Renn, K.A. (2005), Analysis of LGBT identity development models and implications for practice. New Directions for Student Services, 2005: 25-39. doi:10.1002/ss.171.

Borrego, M., Foster, M.J. and Froyd, J.E. (2014), Systematic Literature Reviews in Engineering Education and Other Developing Interdisciplinary Fields. J. Eng. Educ., 103: 45-76. doi: $10.1002 /$ jee. 20038

Boudreau, K., \& DiBiasio, D., \& Quinn, P., \& Reidinger, Z. (2018), Exploring Inclusive Spaces for LGBTQ Engineering Students. In 2018 CoNECD - The Collaborative Network for Engineering and Computing Diversity Conference, Crystal City, Virginia. https://peer.asee.org/29537.

Bowman, K., \& Madsen, L. (2018). Queer identities in materials science and engineering. MRS Bulletin, 43(4), 303-307. doi:10.1557/mrs.2018.83

Burgess, D., Lee, R., Tran, A., \& van Ryn, M. (2007). Effects of Perceived Discrimination on Mental Health and Mental Health Services Utilization Among Gay, Lesbian, Bisexual and Transgender Persons, Journal of LGBT Health Research, 3:4, 1-14, DOI: $10.1080 / 15574090802226626$

Cech, E., \& Waidzunas, T. (2009). "Engineers Who Happen To Be Gay": Lesbian, Gay, And Bisexual Students' Experiences In Engineering. In 2009 ASEE Annual Conference \& Exposition, Austin, Texas. https://peer.asee.org/5583

Cech, E. A., \& Waidzunas, T. J. (2011) Navigating the heteronormativity of engineering: the experiences of lesbian, gay, and bisexual students, Engineering Studies, 3:1, 1-24, DOI: $10.1080 / 19378629.2010 .545065$

Cech, E. A. (2013). The Veiling of Queerness: Depoliticization and the Experiences of LGBT Engineers. In 2013 ASEE Annual Conference \& Exposition, Atlanta, Georgia. https://peer.asee.org/22628

Cech, E. A., \& Waidzunas, T. J., \& Farrell, S. (2016), Engineering Deans' Support For LGBTQ Inclusion. In 2016 ASEE Annual Conference \& Exposition, New Orleans, Louisiana. $10.18260 /$ p.26633

Cech, E. A., \& Waidzunas, T. J., \& Farrell, S. (2017). The Inequality of LGBTQ Students in U.S. Engineering Education: Report on a Study of Eight Engineering Programs. In 2017 ASEE Annual Conference \& Exposition, Columbus, Ohio. https://peer.asee.org/28981

Cech, E.A. and Rothwell, W.R. (2018), LGBTQ Inequality in Engineering Education. J. Eng. Educ., 107: 583-610. doi:10.1002/jee.20239\

D'Augelli, A. R. (1992). Lesbian and gay male undergraduates' experiences of harassment and fear on campus. Journal of Interpersonal Violence, 7, 383-395.

Dilley, P. (2002). Queer man on campus: A history of non-heterosexual college men, 19452000. New York: Routledge.

Duran, A. (2019). Queer and of color: A systematic literature review on queer students of color in higher education scholarship. Journal of Diversity in Higher Education, 12(4), 390400. https://doi.org/10.1037/dhe0000084

Evans, N. J. (2002). The impact of an LGBT Safe Zone project on campus climate. Journal of College Student Development, 43(4), 522-539.

Evans, N.J., \& Herriott, T.K. (2004). Freshmen Impressions: How Investigating the Campus Climate for LGBT Students Affected Four Freshmen Students. Journal of College Student Development 45(3), 316-332. doi:10.1353/csd.2004.0034. 
Farrell, S., Guerra, R. C. C., Longo, A., Tsanov, R., Cech, E. A., \& Waidzunas, T. J. (2017). ASEE Safe Zone workshops and Virtual Community of Practice to promote LGBTQ equality in engineering. In ASEE Annual Conference and Exposition, Conference Proceedings (Vol. 2017-June). American Society for Engineering Education. https://doi.org/10.18260/p.26284

Faulkner, W. (2000). Dualisms, Hierarchies and Gender in Engineering. Social Studies of Science, 30(5), 759-792. https://doi.org/10.1177/030631200030005005

Gold, M. (2019). The ABCs of L.G.B.T.Q.I.A. Retrieved February 2, 2020, from https://www.nytimes.com/2018/06/21/style/lgbtq-gender-language.html

Greathouse, M., BrckaLorenz, A., Hoban, M., Huesman Jr., R., Rankin, S., \& Stolzenberg, E. B. (2018). Queer-Spectrum and Trans-Spectrum Student Experiences in American Higher Education. https://doi.org/10.7282/T3-44FH-3B16

Guerra, R. C. C., Farrell, S., \& Longo, A. (2016). Promoting LGBTQ equality in engineering via online Safe Zone workshops. In Proceedings - Frontiers in Education Conference, FIE (Vol. 2016-November). Institute of Electrical and Electronics Engineers Inc. https://doi.org/10.1109/FIE.2016.7757731

Haverkamp, A. (2018). The Complexity of Nonbinary Gender Inclusion in Engineering Culture. In 2018 ASEE Annual Conference \& Exposition, Salt Lake City, Utah. https://peer.asee.org/31084

Haverkamp, A., \& Butler, A., \& Pelzl, N. S., \& Bothwell, M. K., \& Montfort, D., \& Driskill, Q. (2019), Exploring Transgender and Gender Nonconforming Engineering Undergraduate Experiences through Autoethnography. In 2019 CoNECD - The Collaborative Network for Engineering and Computing Diversity, Crystal City, Virginia. https://peer.asee.org/31764

Hughes, B.E. (2017). "Managing by Not Managing": How Gay Engineering Students Manage Sexual Orientation Identity. Journal of College Student Development 58(3), 385-401. doi:10.1353/csd.2017.0029.

Hughes, B. E. (2018). Coming out in STEM: Factors affecting retention of sexual minority STEM students. Sci. Adv. 4, eaao6373.

Johnson, P. E. (2001) "Quare" studies, or (almost) everything I know about queer studies I learned from my grandmother, Text and Performance Quarterly, 21:1, 1-25, DOI: $10.1080 / 10462930128119$

Lange, A.C., Duran, A., \& Jackson, R. (2019). The State of LGBT and Queer Research in Higher Education Revisited: Current Academic Houses and Future Possibilities. Journal of College Student Development 60(5), 511-526. doi:10.1353/csd.2019.0047.

Leyva, L., \& Massa, J., \& Battey, D. (2016). Queering Engineering: A Critical Analysis of the Gendered Technical/Social Dualism in Engineering and Engineering Education Research. In 2016 ASEE Annual Conference \& Exposition, New Orleans, Louisiana. $10.18260 /$ p.26026

Linley, J. L., Renn, K. A., \& Woodford, M. R. (2018). Examining the Ecological Systems of LGBTQ STEM Majors. Journal of Women and Minorities in Science and Engineering, 24(1), 1-16.

Lopez, G. \& Chims, N. (1993) Classroom Concerns of Gay and Lesbian Students: The Invisible Minority, College Teaching, 41:3, 97-103, DOI: $\underline{10.1080 / 87567555.1993 .9926788}$ 
Marine, S. B., \& Nicolazzo, Z. (2014). Names that matter: Exploring the tensions of campus LGBTQ centers and trans* inclusion. Journal of Diversity in Higher Education, 7(4), 265-281. https://doi.org/10.1037/a0037990

Means, D.R. (2017). "Quaring” Spirituality: The Spiritual Counterstories and Spaces of Black Gay and Bisexual Male College Students. Journal of College Student Development 58(2), 229-246. doi:10.1353/csd.2017.0017.

Ohland, M.W., Brawner, C.E., Camacho, M.M., Layton, R.A., Long, R.A., Lord, S.M. and Wasburn, M.H. (2011), Race, Gender, and Measures of Success in Engineering Education. Journal of Engineering Education, 100: 225-252. doi:10.1002/j.21689830.2011.tb00012.x

Pitcher, E. N., Camacho, T. P., Renn, K. A., \& Woodford, M. R. (2018). Affirming policies, programs, and supportive services: Using an organizational perspective to understand LGBTQ+ college student success. Journal of Diversity in Higher Education, 11(2), 117132. https://doi.org/10.1037/dhe0000048

Renn, K. A. (2010). LGBT and Queer Research in Higher Education: The State and Status of the Field. Educational Researcher, 39(2), 132-141. https://doi.org/10.3102/0013189X10362579

Riley, D. M. (2013). The Island of Other: Making space for embodiment of difference in engineering. In 2013 ASEE Annual Conference \& Exposition, Atlanta, Georgia. https://peer.asee.org/22606

Riley, D. M. (2017). Rigor/Us: Building Boundaries and Disciplining Diversity with Standards of Merit. Engineering Studies, 9(3), 249-265. https://doi.org/10.1080/19378629.2017.1408631

Rohde, J., Kirn, A., \& Godwin, A. (2017). Engineering Allies: The Personalities of Cisgender Engineering Students. In 2017 ASEE Annual Conference \& Exposition Proceedings, Columbus, Ohio. doi: 10.18260/1-2-28248

Slaton, A. E., \& Pawley, A. L. (2018). The power and politics of engineering education research design: Saving the 'Small N'. Engineering Studies, 11, 1- 25. https://doi.org/10.1080/19378629.2018.1550785

Sears, B., \& Mallory, C. (2011). Documented Evidence of Employment Discrimination \& Its Effects on LGBT People. UCLA: The Williams Institute. Retrieved from https://escholarship.org/uc/item/03m1g5sg

Stout, J. G. and H. M. Wright, H. M. (2015). Lesbian, Gay, Bisexual, Transgender, and Queer students' sense of belonging in computing. In 2015 Research in Equity and Sustained Participation in Engineering, Computing, and Technology (RESPECT), Charlotte, NC. pp. 1-5. doi: 10.1109/RESPECT.2015.7296501

Stout, J. G., \& Wright, H. M. (2016). Lesbian, Gay, Bisexual, Transgender, and Queer Students' Sense of Belonging in Computing: An Intersectional Approach. Computing in Science and Engineering, 18(3), 24-30. https://doi.org/10.1109/MCSE.2016.45

Trenshaw, K. F., Hetrick, A., Oswald, R. F., Vostral, S. L., \& Loui, M. C. (2013). Lesbian, gay, bisexual, and transgender students in engineering: Climate and perceptions. In 2013 IEEE Frontiers in Education Conference (FIE). doi: 10.1109/fie.2013.6685028

Trenshaw, K. F. (2018). Half as Likely: The Underrepresentation of LGBTQ+ Students in Engineering. In 2018 CoNECD - The Collaborative Network for Engineering and Computing Diversity Conference, Crystal City, Virginia. https://peer.asee.org/29541 
Woodford, M. R., Silverschanz, P., Swank, E., Scherrer, K. S., \& Raiz, L. (2012). Predictors of Heterosexual College Students' Attitudes Toward LGBT People. Journal of LGBT Youth, 9:4, 297-320, DOI: 10.1080/19361653.2012.716697 
Appendix A - Engineering and Engineering Education Literature Reviewed

\begin{tabular}{|c|c|c|c|c|c|}
\hline Reference & Authors & $\begin{array}{c}\text { Publication } \\
\text { Type }\end{array}$ & $\begin{array}{l}\text { Discipline of } \\
\text { Publication } \\
\text { Venue }\end{array}$ & Methodology & Theme \\
\hline
\end{tabular}

\begin{tabular}{|c|c|c|c|c|c|c|}
\hline $\begin{array}{l}\text { Boudreau et } \\
\text { al., } 2018\end{array}$ & $\begin{array}{l}\text { Boudreau, K., } \\
\text { DiBiasio, D., } \\
\text { Quinn, P., \& } \\
\text { Reidinger, Z. }\end{array}$ & $\begin{array}{l}\text { Conference } \\
\text { Proceeding }\end{array}$ & $\begin{array}{l}\text { Engineering } \\
\text { Education }\end{array}$ & $\begin{array}{l}\text { Mixed- } \\
\text { Methods }\end{array}$ & Policy, Climate & $\begin{array}{l}\text { Examines the best } \\
\text { practices for creating } \\
\text { inclusive spaces for } \\
\text { LGBTQIA+ engineering } \\
\text { students }\end{array}$ \\
\hline
\end{tabular}

\begin{tabular}{|c|c|c|c|c|c|c|}
\hline $\begin{array}{l}\text { Bownam \& } \\
\text { Madsen, } \\
2018\end{array}$ & $\begin{array}{l}\text { Bowman, K., \& } \\
\text { Madsen, L. }\end{array}$ & Other & $\begin{array}{l}\text { Materials } \\
\text { Engineering }\end{array}$ & Other & Policy & $\begin{array}{l}\text { Special feature in the } \\
\text { Materials Research Society } \\
\text { bulletin; Discusses the } \\
\text { need for inclusive diversity } \\
\text { statements }\end{array}$ \\
\hline
\end{tabular}

\begin{tabular}{|c|c|c|c|c|c|c|}
\hline $\begin{array}{l}\text { Cech \& } \\
\text { Waidzunas, } \\
2009\end{array}$ & $\begin{array}{l}\text { Cech, E. A., \& } \\
\text { Waidzunas, T. }\end{array}$ & $\begin{array}{l}\text { Conference } \\
\text { Proceeding }\end{array}$ & $\begin{array}{l}\text { Engineering } \\
\text { Education }\end{array}$ & Qualitative & $\begin{array}{l}\text { Coping } \\
\text { Strategies, LGB } \\
\text { Monolith, } \\
\text { Technical/Social } \\
\text { Dualism }\end{array}$ & $\begin{array}{l}\text { WIP for Cech \& } \\
\text { Waidzunas }(2011) \text {; First } \\
\text { Engr. Ed. publication } \\
\text { regarding the LGBTQIA+ } \\
\text { experience }\end{array}$ \\
\hline
\end{tabular}




\begin{tabular}{|c|c|c|c|c|c|c|}
\hline $\begin{array}{l}\text { Cech \& } \\
\text { Waidzunas, } \\
2011\end{array}$ & $\begin{array}{l}\text { Cech, E. A., \& } \\
\text { Waidzunas, T. } \\
\text { J. }\end{array}$ & $\begin{array}{l}\text { Journal } \\
\text { Article }\end{array}$ & $\begin{array}{l}\text { Engineering } \\
\text { Education }\end{array}$ & Qualitative & $\begin{array}{l}\text { Climate, Coping } \\
\text { Strategies, LGB } \\
\text { Monolith, } \\
\text { Technical/Social } \\
\text { Dualism }\end{array}$ & $\begin{array}{l}\text { First Eng. Ed. Journal } \\
\text { article detailing the } \\
\text { experiences \& needs of } \\
\text { LGBTQIA+ engineering } \\
\text { students }\end{array}$ \\
\hline Cech, 2013 & Cech, E. A. & $\begin{array}{l}\text { Conference } \\
\text { Proceeding }\end{array}$ & $\begin{array}{l}\text { Engineering } \\
\text { Education }\end{array}$ & Qualitative & $\begin{array}{l}\text { Climate, } \\
\text { Technical/Social } \\
\text { Dualism }\end{array}$ & $\begin{array}{l}\text { Inspired by prior } \\
\text { interviews, Cech discusses } \\
\text { how queerness is erased in } \\
\text { 'apolitical' engineering } \\
\text { spaces }\end{array}$ \\
\hline $\begin{array}{l}\text { Cech et al., } \\
2016\end{array}$ & $\begin{array}{l}\text { Cech, E. A., } \\
\text { Waidzunas, T. } \\
\text { J., \& Farrell, S. }\end{array}$ & $\begin{array}{l}\text { Conference } \\
\text { Proceeding }\end{array}$ & $\begin{array}{l}\text { Engineering } \\
\text { Education }\end{array}$ & Quantitative & Climate & $\begin{array}{l}\text { An exploration into } \\
\text { engineering deans' } \\
\text { perceptions of their } \\
\text { programs' climate for } \\
\text { LGBTQIA+ students }\end{array}$ \\
\hline $\begin{array}{l}\text { Cech et al., } \\
2017\end{array}$ & $\begin{array}{l}\text { Cech, E. A., } \\
\text { Waidzunas, T. } \\
\text { J., \& Farrell, S. }\end{array}$ & $\begin{array}{l}\text { Conference } \\
\text { Proceeding }\end{array}$ & $\begin{array}{l}\text { Engineering } \\
\text { Education }\end{array}$ & Quantitative & $\begin{array}{l}\text { Climate, LGB } \\
\text { Monolith }\end{array}$ & $\begin{array}{l}\text { WIP for Cech \& Rothwell } \\
\text { (2017); Details methods } \\
\text { used to gather quantitative } \\
\text { data to explore engineering } \\
\text { climates for LGBTQIA+ } \\
\text { students }\end{array}$ \\
\hline
\end{tabular}




\begin{tabular}{|c|c|c|c|c|c|c|}
\hline $\begin{array}{l}\text { Cech \& } \\
\text { Rothwell, } \\
2018\end{array}$ & $\begin{array}{l}\text { Cech, E. A., \& } \\
\text { Rothwell, W. R. }\end{array}$ & $\begin{array}{l}\text { Journal } \\
\text { Article }\end{array}$ & $\begin{array}{l}\text { Engineering } \\
\text { Education }\end{array}$ & Quantitative & $\begin{array}{l}\text { Climate, LGB } \\
\text { Monolith }\end{array}$ & $\begin{array}{l}\text { Large-scale analysis of } \\
\text { climate for LGBTQIA+ } \\
\text { engineering students } \\
\text { within engineering } \\
\text { programs }\end{array}$ \\
\hline
\end{tabular}

\begin{tabular}{|c|c|c|c|c|c|c|}
\hline $\begin{array}{l}\text { Farrell et al., } \\
2017\end{array}$ & $\begin{array}{l}\text { Farrell, S., } \\
\text { Guerra, R. C. } \\
\text { C., Longo, A., } \\
\text { Tsanov, R., } \\
\text { Cech, E. A., \& } \\
\text { Waidzunas, T. } \\
\text { J. }\end{array}$ & $\begin{array}{l}\text { Conference } \\
\text { Proceeding }\end{array}$ & $\begin{array}{l}\text { Engineering } \\
\text { Education }\end{array}$ & Other & Policy & $\begin{array}{l}\text { WIP; Details regarding a } \\
\text { SafeZone effectiveness } \\
\text { research study }\end{array}$ \\
\hline $\begin{array}{l}\text { Guerra et al., } \\
2016\end{array}$ & $\begin{array}{l}\text { Guerra, R. C. } \\
\text { C., Farrell, S., } \\
\text { \& Longo, A. }\end{array}$ & $\begin{array}{l}\text { Conference } \\
\text { Proceeding }\end{array}$ & $\begin{array}{l}\text { Engineering } \\
\text { Education }\end{array}$ & Quantitative & Policy & $\begin{array}{l}\text { WIP; Outlines a research } \\
\text { project regarding the } \\
\text { effectiveness of SafeZone } \\
\text { training in engineering } \\
\text { programs and how to } \\
\text { examine their effectiveness }\end{array}$ \\
\hline
\end{tabular}




\begin{tabular}{llll}
\hline $\begin{array}{l}\text { Haverkamp, Haverkamp, A. } \begin{array}{l}\text { Conference } \\
\text { Proceeding }\end{array} \\
\text { Education }\end{array}$ & $\begin{array}{l}\text { Engineering } \\
\text { Edualitative }\end{array}$ & $\begin{array}{c}\text { Policy, Climate } \\
\text { Introduces a discussion } \\
\text { surrounding the challenges } \\
\text { of remembering trans and } \\
\text { nonconforming genders in } \\
\text { engineering education } \\
\text { research }\end{array}$
\end{tabular}

\begin{tabular}{|c|c|c|c|c|c|c|}
\hline $\begin{array}{l}\text { Haverkamp } \\
\text { et al., } 2019\end{array}$ & $\begin{array}{l}\text { Haverkamp, A., } \\
\text { Butler, A., } \\
\text { Pelzl, N. S., } \\
\text { Bothwell, M. } \\
\text { K., Montfort, } \\
\text { D., \& Driskill, } \\
\text { Q. }\end{array}$ & $\begin{array}{l}\text { Conference } \\
\text { Proceeding }\end{array}$ & $\begin{array}{l}\text { Computer } \\
\text { Engineering }\end{array}$ & Qualitative & $\begin{array}{l}\text { Climate, Coping } \\
\text { Strategies }\end{array}$ & $\begin{array}{l}\text { Collaborative } \\
\text { autoethnography with two } \\
\text { TGNC engineering } \\
\text { students, who detail their } \\
\text { experiences and coping } \\
\text { mechanisms whilst } \\
\text { pursuing engineering }\end{array}$ \\
\hline $\begin{array}{l}\text { Hughes, } \\
2017\end{array}$ & Hughes, B. E. & $\begin{array}{l}\text { Journal } \\
\text { Article }\end{array}$ & $\begin{array}{l}\text { College } \\
\text { Student } \\
\text { Development }\end{array}$ & Qualitative & $\begin{array}{l}\text { Identity } \\
\text { Development, } \\
\text { LGB Monolith }\end{array}$ & $\begin{array}{l}\text { Explores how gay } \\
\text { engineering students } \\
\text { reconcile their LGBTQIA+ } \\
\text { and engineering identities }\end{array}$ \\
\hline
\end{tabular}




\begin{tabular}{|c|c|c|c|c|c|c|}
\hline $\begin{array}{l}\text { Hughes, } \\
2018\end{array}$ & Hughes, B. E. & $\begin{array}{l}\text { Journal } \\
\text { Article }\end{array}$ & $\begin{array}{l}\text { STEM } \\
\text { General }\end{array}$ & Quantitative & $\begin{array}{l}\text { Climate, LGB } \\
\text { Monolith }\end{array}$ & $\begin{array}{l}\text { Examines how being LGB } \\
\text { (among other factors) } \\
\text { affects STEM students' } \\
\text { retention rates }\end{array}$ \\
\hline
\end{tabular}

\begin{tabular}{|c|c|c|c|c|c|c|}
\hline $\begin{array}{l}\text { Leyva et al., } \\
2016\end{array}$ & $\begin{array}{l}\text { Leyva, L., } \\
\text { Massa, J., \& } \\
\text { Battey, D. }\end{array}$ & $\begin{array}{l}\text { Conference } \\
\text { Proceeding }\end{array}$ & $\begin{array}{l}\text { Engineering } \\
\text { Education }\end{array}$ & Qualitative & $\begin{array}{l}\text { Technical/Social } \\
\text { Dualism }\end{array}$ & $\begin{array}{l}\text { Critical analysis of the } \\
\text { technical/social dualism } \\
\text { framework in engineering } \\
\text { education literature } \\
\text { through a queer theory lens }\end{array}$ \\
\hline
\end{tabular}

\begin{tabular}{|c|c|c|c|c|c|c|}
\hline $\begin{array}{l}\text { Linley et al., } \\
2018\end{array}$ & $\begin{array}{l}\text { Linley, J. L., } \\
\text { Ren, K. A., \& } \\
\text { Woodford, M. } \\
\text { R. }\end{array}$ & $\begin{array}{l}\text { Journal } \\
\text { Article }\end{array}$ & $\begin{array}{l}\text { Engineering } \\
\text { General }\end{array}$ & Qualitative & $\begin{array}{l}\text { Technical/Social } \\
\text { Dualism, } \\
\text { Climate }\end{array}$ & $\begin{array}{l}\text { Examines ecological } \\
\text { climates for LGBTQIA+ } \\
\text { STEM students using a } \\
\text { technical/social dualism } \\
\text { framework }\end{array}$ \\
\hline
\end{tabular}

\begin{tabular}{|c|c|c|c|c|c|c|}
\hline Riley, 2013 & Riley, D. M. & $\begin{array}{l}\text { Conference } \\
\text { Proceeding }\end{array}$ & $\begin{array}{l}\text { Engineering } \\
\text { Education }\end{array}$ & Other & $\begin{array}{l}\text { Critical } \\
\text { Analysis (?) }\end{array}$ & $\begin{array}{l}\text { Explores embodiment and } \\
\text { heteronormativity in } \\
\text { engineering spaces as } \\
\text { barriers for LGBTQ and } \\
\text { disabled students }\end{array}$ \\
\hline
\end{tabular}




\begin{tabular}{|c|c|c|c|c|c|c|}
\hline $\begin{array}{l}\text { Rohde et al., } \\
2017\end{array}$ & $\begin{array}{l}\text { Rohde, J., Kirn } \\
\text { A., \& Godwin, } \\
\text { A. }\end{array}$ & $\begin{array}{l}\text { Conference } \\
\text { Proceeding }\end{array}$ & $\begin{array}{l}\text { Engineering } \\
\text { Education }\end{array}$ & Quantitative & Climate & $\begin{array}{l}\text { Examines attributes of } \\
\text { cisgender-identifying engr. } \\
\text { students compared to those } \\
\text { identifying as M/F }\end{array}$ \\
\hline $\begin{array}{l}\text { Stout \& } \\
\text { Wright, } \\
2015\end{array}$ & $\begin{array}{l}\text { Stout, J. G., \& } \\
\text { Wright, H. M. }\end{array}$ & $\begin{array}{l}\text { Conference } \\
\text { Proceeding }\end{array}$ & $\begin{array}{l}\text { Computer } \\
\text { Engineering }\end{array}$ & Quantitative & Climate & $\begin{array}{l}\text { WIP for Stout \& Wright } \\
(2016)\end{array}$ \\
\hline $\begin{array}{l}\text { Stout \& } \\
\text { Wright, } \\
2016\end{array}$ & $\begin{array}{l}\text { Stout, J. G., \& } \\
\text { Wright, H. M. }\end{array}$ & $\begin{array}{l}\text { Journal } \\
\text { Article }\end{array}$ & $\begin{array}{l}\text { Computer } \\
\text { Engineering }\end{array}$ & Quantitative & Climate & $\begin{array}{l}\text { Series of quantitative } \\
\text { studies showing that } \\
\text { LGBTQ students lacking a } \\
\text { sense of belonging are } \\
\text { more likely to leave their } \\
\text { computing programs (UG } \\
\text { or Graduate) }\end{array}$ \\
\hline $\begin{array}{l}\text { Trenshaw et } \\
\text { al., } 2013\end{array}$ & $\begin{array}{l}\text { Trenshaw, K. } \\
\text { F., Hetrick, A., } \\
\text { Oswald, R. F., } \\
\text { Vostral, S. L., } \\
\text { \& Loui, M. C. }\end{array}$ & $\begin{array}{l}\text { Conference } \\
\text { Proceeding }\end{array}$ & $\begin{array}{l}\text { STEM } \\
\text { Education }\end{array}$ & Qualitative & Climate & $\begin{array}{l}\text { WIP; Examines the LGBT } \\
\text { engineering experience; } \\
\text { First publication } \\
\text { examining the TGNC } \\
\text { engineering experience }\end{array}$ \\
\hline $\begin{array}{l}\text { Trenshaw, } \\
2018\end{array}$ & Trenshaw, K. F. & $\begin{array}{l}\text { Conference } \\
\text { Proceeding }\end{array}$ & $\begin{array}{l}\text { Computer } \\
\text { Engineering }\end{array}$ & $\begin{array}{l}\text { Mixed- } \\
\text { Methods }\end{array}$ & Climate & $\begin{array}{l}\text { Examines } \\
\text { underrepresentation of } \\
\text { LGBTQ students in } \\
\text { engineering programs and } \\
\text { how this affects their } \\
\text { experiences }\end{array}$ \\
\hline
\end{tabular}

